\title{
The prey composition of the Barn Owl (Tyto alba) with respect to landscape structure of its hunting area (Zala County, Hungary)
}

\author{
Dávid SzÉP ${ }^{1 *}$, Ákos KLeIN² \& Jenő J. Purger ${ }^{1}$
}

Received: October 12, 2017 - Accepted: December 22, 2017

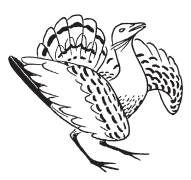

Szép, D., Klein, Á. \& Purger, J. J. 2018. The prey composition of the Barn Owl (Tyto alba) with respect to landscape structure of its hunting area (Zala County, Hungary). - Ornis Hungarica 25(2): 51-64. DOI: 10.1515/orhu-2017-0015

${ }^{x}$ Presented at $1^{\text {st }}$ Hungarian Owl Research Conference held in Pécs on $8^{\text {th }}$ September 2017

\begin{abstract}
The prey composition of the Barn Owl (Tyto alba) can be monitored indirectly by pellet analysis and we used this method to investigate less known small mammal species of Zala County. The number and abundance of small mammal species depend on the structure of the landscape of Barn Owls' hunting area, therefore we analysed landscape features in the surrounding circles with $2 \mathrm{~km}$ radius around the sampling sites. In 2016 we collected 1106 pellets from 13 sampling localities. From the pellets we identified 21 species of 3022 individuals of small mammals (more than $98 \%$ of prey). Among the 21 species there was the rare Parti-colured Bat (Vespertilio murinus) and a new species for the county the Steppe Mouse (Mus spicilegus). Positive correlation was found between the diversity of the small mammal fauna of each sampling site and the landscape complexity (number of the landscape patches) of the Barn Owl hunting area. Relative abundance of the Wood Mouse (Apodemus sylvaticus) showed positive correlation with the number of landscape patches, while the abundance of the Lesser White-toothed Shrew (Crocidura suaveolens), the Miller's Water Shrew (Neomys anomalus), the Striped Field Mouse (Apodemus agrarius) and the Harvest Mouse (Micromys minutus) was higher in hunting areas with more homogenous landscapes. Significant correlations were found between the relative abundance of some small mammal species and the landscape structure of the potential hunting area of owls that confirmed the consistency in habitat preference of some species. Our results proved that the prey-composition of Barn Owls reflects the land use through the distribution and abundance of small mammal species, therefore this method is suitable for ecological analyses of landscape.
\end{abstract}

Keywords: diversity, habitat preference, landscape mosaic, pellets analysis, small mammals

Összefoglalás A gyöngybagoly (Tyto alba) köpetek elemzésével kimutatható a vadászterületükön előforduló kisemlősök faj- és egyedszáma. Ezt az indirekt módszert alkalmaztuk a kevésbé kutatott Zala megyei kisemlősfauna felmérésére. A kisemlösök fajszáma és gyakorisága függ a gyöngybaglyok vadászterületeinek tájszerkezetétől és mintázatától, ezért a köpetgyüjtés helyétől kb. 2 km sugarú körben elemeztük a táj jellemzőit. 2016-ban 13 településről 1106 köpetet gyüjtöttünk. Az előkerült 3022 zsákmányállat maradványainak több mint 98\%-a kisemlős volt. A 21 azonosított faj között volt a ritka fehértorkú denevér (Vespertilio murinus), valamint egy, a megyére nézve új faj, a güzüegér (Mus spicilegus). Az egyes mintavételi helyek kisemlős faunájának diverzitása és a gyöngybaglyok vadászterületeinek mozaikossága (eltérő tájszerkezetủ területfoltok száma) között pozitív korrelációt mutattunk ki. A közönséges erdeiegér (Apodemus sylvaticus) relatív gyakorisága pozitív kapcsolatban állt a táj mozaikosságával, míg a keleti cickány (Crocidura suaveolens), a Miller-vízicickány (Neomys anomalus), a pirók erdeiegér (Apodemus agrarius) és a törpeegér (Micromys minutus) relatív abundanciája nagyobb volt a homogén jellegủ vadászterületeken. Egyes kisemlős fajok relatív gyakorisága és a baglyok potenciális vadászterületének tájszerkezete között szignifikáns összefüggéseket állapítottunk meg, amelyek többsége összhangban volt egyes fajok élöhely preferenciájával. Eredményeink rámutatnak arra, hogy a gyöngybaglyok zsákmányösszetétele az egyes kisemlős fajok egyedszámának megoszlásán keresztül tükrözi a tájhasználatot és így ez a módszer tájökológiai elemzésekre is alkalmas.

Kulcsszavak: diverzitás, élőhely preferencia, mozaikosság, köpet elemzés, kisemlősök 
${ }^{1}$ Department of Ecology, Institute of Biology, University of Pécs, 7624 Pécs, Ifjúság útja 6., Hungary

${ }^{2}$ The Barn Owl Foundation, 8744 Orosztony, Temesvári utca 8., Hungary

*corresponding author: szeep.david@gmail.com

\section{Introduction}

Barn Owls mainly feed on small mammals and the indigestible parts of the consumed animals are regurgitated in breeding and roost sites in the form of elongated round shape pellets (Mikkola 1983, März 2011). Pellet analysis (identification of species and their abundance on the basis of bone remains) can be used in survey of the small mammal fauna of the Barn Owls' hunting area (Taylor 1994, Seamon \& Adler 1996). Pellets can be used as the most reliable methods of assessing small mammal populations and their change over time, however some prey proportion in pellets fluctuate and indicate non-selective feeding, or opportunism as adaptation to changing local circumstances in their foraging (Meek et al. 2012). Upon long-term studies of their diet content spatial and temporal changes of the small mammal composition in their hunting area can be detected (Bunn et al. 1982, Tores et al. 2005). This method is also suitable for detecting the effect of land use changes on small mammal communities (Cooke et al. 1996, de la Peña et al. 2003, Rodríguez \& Peris 2007).

Small mammal community composition estimated upon pellets was better represented compared to estimates from the standard direct sampling methods, e.g. trapping (Heisler et al. 2016). Advantage of the pellet analysis in contrast to the trapping is that the rare small mammal species are more often detected by using this indirect method (Torre et al. 2004, 2015). Owls are an effective alternative for landscape-level assessments of small mammal communities (Heisler et al. 2016).

Pellet studies have a long tradition in Hungary, but this method has been used primarily in fauna surveys (e.g. Schmidt 1967a, Kalivoda 1999, Bihari et al. 2007). The collection of pellets was performed irregularly with the exception of some counties, so these results are difficult to use for ecological landscape analysis. In Zala County, during the last century there were only sporadic collections of pellets (Greschik 1911, Éhik 1953, Schmidt 1974, 1976, Lázár 1983, Ács 1986, Nagy 1994, Fehér 1996, Fehér et al. 2005, Bihari et al. 2007, Szép \& Purger 2013), therefore little is known about the diet composition of the Barn Owls and the presence and abundance of small mammal species. In this county mosaic agricultural landscape predominated and nearly one-third of the area is covered by forests (Király et al. 2008, Dövényi et al. 2010). Our previous studies conducted in the north-eastern part of the county which showed that the small mammal communities were affected also by changes in land use (Szép \& Purger 2013).

The goal of the present study was to collect Barn Owl pellets from different locations of Zala County, and on the basis of the prey remnants, to study the presence and abundance of small mammal species; to investigate the effect of landscape structure and mosaic of the Barn Owls' hunting areas on their prey composition. 


\section{Materials and methods}

The collection of pellets in Zala County was carried out in 2016 by the members of the Barn Owl Foundation (BOF). More than 90 buildings, mostly churches were inspected and out of 13 locations 15 samples of pellets were collected. These pellets were obtained from the area of 9 UTM squares (XM16, XM25, XM26, XM37, XM46, XM47, XM58, XM65, XM66) (Figure 1, Table 1a,b).

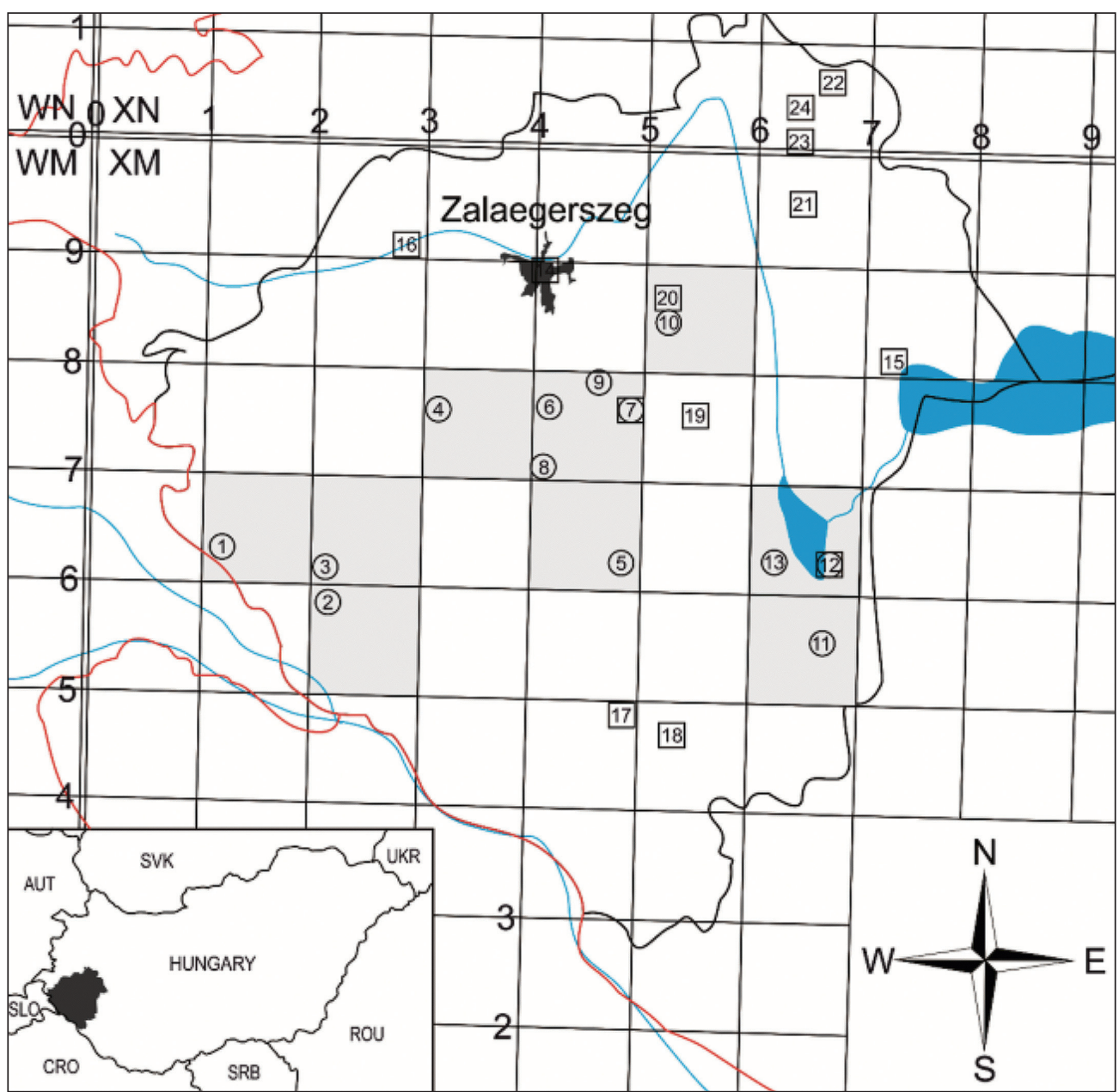

Figure 1. Sampling locations of own data in circle and data from earlier studies in square in the UTM map of Zala County (1 - Rédics, 2 - Szécsisziget, 3 - Iklódbördőce, 4 - Barlahida, 5 - Pölöskefö, 6 - Bak, 7 - Pölöske (Ács 1984), 8 - Söjtör, 9 - Zalaszentmihály, 10 - Misefa, 11 - Zalakomár, 12 - Balatonmagyaród (Nagy 1994, Fehér et al. 2005), 13 - Garabonc, 14 - Zalaegerszeg (Greschik 1911), 15 - Keszthely (Éhik 1953, Fehér 1996), 16 - Zalaszentgyörgy, 17 - Homokkomárom, 18 - Nagykanizsa, 19 - Pacsa, 20 - Nagykapornak, 21 - Vindornyaszőlős (Schmidt 1976), 22 - Mihályfa, (Lázár 1983), 23 - Kisgörbő és 24 - Óhíd (Szép \& Purger 2013)

1. ábra A saját mintavételi helyek körökben, az irodalomban közölt mintavételi helyek négyzetekben Zala megye UTM térképén ábrázolva 
In most samples the exact age of the pellets could not be estimated, they are considered to be formed during 2016, therefore the dates indicate the time of collection (Table la,b). The pellets were disassembled under a fume hood using a dry technique and the single pellets were broken down by hand, using tweezers and toothbrushes (Schmidt 1967b). The number of small mammals was based on the number of skulls and their corresponding jaws. Small mammals were identified on the basis of skeletal parameters of skulls, jaws and teeth (Schmidt 1967b, Ujhelyi 1989, Kryštufek \& Janžekovič 1999, März 2011). The identification of the species belonging to the Sylvaemus subgenus was done by following the method of Trrtković (1979). The two species of the Neomys genus, the Water Shrew (Neomys fodiens) and the Miller's Water Shrew (N. anomalus) were identified by using description of Tvrtković et al. (1980). For the determination of the Eastern House Mouse (Mus musculus) and the Steppe Mouse (M. spicilegus) we used the identification key by Macholán (1996). Problematic or damaged skeletal items belonging to the Apodemus, Mus and Rattus genera were listed as Apodemus sp., Mus sp. and Rattus sp. (Table 1a,b). The order of mammal species and the scientific names was used as described by Bihari et al. (2007).

The diversity of small mammals in each sampling site was characterised by the Shannon Weaver (H) index (Shannon \& Weaver 1949, Hammer et al. 2001). For landscape structure and mosaic analysis we used the map of the national scale CORINE Land Cover Project of 2012, 1:50 000 (Feranec et al. 1995). On this map circles with $2 \mathrm{~km}$ radius around the sampling sites were marked that represent the hunting areas of Barn Owls (Lovari et al. 1976, Martinez \& Zuberogoitia 2004, Torre et al. 2015). In these circles we examined the distribution of CORINE Land Cover classes (e.g. broad-leaved forest, peatbogs, vineyards, etc.) as types of landscape structure using ArcGIS 10.0 program. The landscape mosaic was calculated as the number of patches within the circles. The relationship between landscape mosaic and diversity of small mammals was analysed by Spearmen's rank correlation (Hammer et al. 2001). Subsequently, by the same method, we investigated the correlation between the ratio of each landscape structure, mosaic and the relative abundance of small mammal species, and only the positive correlations were taken into consideration (Hammer et al. 2001).

\section{Results and discussion}

In 1106 Barn Owl pellets collected in Zala County 3022 prey items were found (Table 1a,b). In the diet of Barn Owls in the studied area small mammals were dominant (98.3\%) while birds, amphibians and insects accounted only $1.7 \%$ (Table 1a,b). The dominance of small mammals can be explained by the fact that Barn Owl usually for hunting selects vole-rich habitats (Askew et al. 2007) and also by the tendency of decrease in abundancy of the other potential prey, e.g. invertebrates (Roulin 2016a).

\section{Faunistic analysis of small mammals}

The remains of 2972 prey individuals found in the pellets belong to 21 small mammal taxa (Table 1a,b). Altogether $35.33 \%$ of the mammalian prey of the Barn Owl belonged to the 
Soricomorpha order. This is an average for the one year and for the large part of the Zala County and it is comparable with the values found in other regions, e.g. with the neighbours Somogy County where the proportion of Soricomorpha varied between 42 and 47\% (Purger 2014, 2016). These proportions may refer not only to the character of the small mammal fauna, but also to the large-scale structure of the landscape (Szücs et al. 2014). Proportion of insectivorous small mammals (shrews and moles) can also change in time, and its decline has been shown by the analysis of 815 papers about the diet of the European Barn Owl. According to Roulin (2016b) the consumption of shrews and moles declined between 1860 and 2014. This suggests that the impoverished invertebrate communities due to global changes affected a large range of animals up to top predators (Roulin 2016b).

Common Shrew (Sorex araneus) was detected in each sample and proved to be the most common species in Pölöskefö (Table 1a,b), confirming the finding of Schmidt (1973) that this species has a dominant role in the diet of Barn Owls in the western part of Hungary. The Bi-coloured White-toothed Shrew (Crocidura leucodon), the Lesser White-toothed Shrew (C. suaveolens) and the Pygmy Shrew (S. minutus) did not appear from the small samples (Table 1a,b). The four species mentioned above have already been shown in several settlements, in Pacsa (Schmidt 1976), Mihályfa (Lázár 1983), Pölöske (Ács 1984), Balatonmagyaród (Nagy 1994), Kisgörbő and Óhíd (Szép \& Purger 2013). Only the Common Shrew, the Bi-coloured White-toothed Shrew and the Lesser White-toothed Shrew were found in Nagykapornak, and in Nagykanizsa only the Lesser White-toothed Shrew was detectable (Schmidt 1976). The remains of the Miller's Water Shrew were found in the area of six UTM squares, while the Water Shrew was identified in only four squares (Table 1a,b). The Water Shrew was found only in Pacsa (Schmidt 1976) and Balatonmagyaród (Nagy 1994), the Miller's Water Shrew was registered in Kisgörbö (Szép \& Purger 2013), while both species were found already in Mihályfa (Lázár 1983), Pölöske (Ács 1984) and Óhíd (Szép \& Purger 2013). The remains of Common Mole (Talpa europaea) were found only in Söjtör (Table 1a,b), but previously was proved in Zalaegerszeg (Greschik 1911), in Pacsa (Schmidt 1976) and in Mihályfa (Lázár 1983). It is a common species (Bihari 2007a), but rarely preyed because of their underground lifestyle.

From the pellets collected at Szécsisziget a remain of the Parti-coloured Bat (Vespertilio murinus) belonging to bats (Chiroptera) was found (Table 1a). This species is considered rare in Hungary (Estók et al. 2007), so far in Zala County it has been known from Balatonmagyaród (XM66), and was found in Barn Owl pellets in 1995 (Fehér et al. 2005). The Barn Owls rarely prey bats, but in the pellets that were found in the county contained the remains of Noctule (Nyctalus noctula) in Keszthely (Fehér 1996) and Grey Long-eared Bat (Plecotus austriacus) in Pacsa (Schmidt \& Topál 1971) and Óhíd (Szép \& Purger 2013). Barn Owls in Europe usually capture bats opportunistically, therefore the share of bats their diet $(0.12 \%)$ is low (Roulen \& Christe 2013).

In Zala County the largest proportion (64.64\%) of the Barn Owl's mammalian prey was identified as rodents (Rodentia), while in Somogy County the proportion of rodents were lower (53-57\%) (Purger 2014, 2016) and this difference can be explained by discrepancy in sampling methods, and by variance in land use. The presence of the Common Dormouse (Muscardinus avellanarius) was detected from the four largest samples (Söjtör, 
Table 1a. Number of prey items in pellets of Barn Owls in sample sites (1-7) 1a. táblázat A köpet-lelőhelyekről (1-7) előkerült zsákmányállatok egyedszáma

\begin{tabular}{|c|c|c|c|c|c|c|c|c|}
\hline Site number & 1. & 2. & 3a. & $3 b$. & 4. & 5. & 6. & 7. \\
\hline 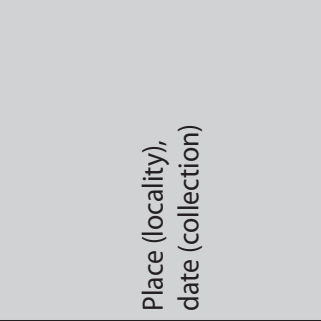 & 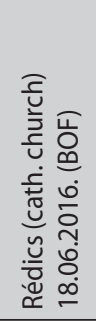 & 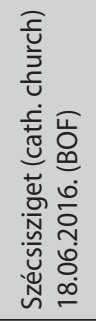 & 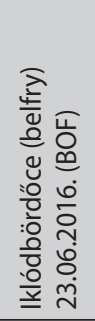 & 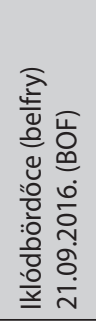 & 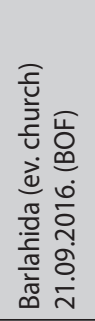 & 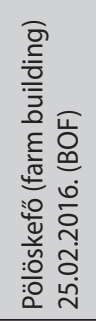 & 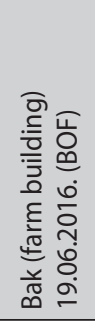 & 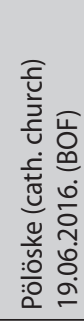 \\
\hline UTM $(10 \times 10 \mathrm{~km})$ & XM16 & $\mathrm{XM} 25$ & $\mathrm{XM} 26$ & $\mathrm{XM} 26$ & XM37 & XM46 & XM47 & XM47 \\
\hline Crocidura leucodon & 9 & 5 & 42 & 9 & 3 & 8 & 0 & 7 \\
\hline Crocidura suaveolens & 13 & 10 & 46 & 11 & 3 & 14 & 0 & 9 \\
\hline Sorex araneus & 63 & 23 & 129 & 7 & 2 & 89 & 1 & 27 \\
\hline Sorex minutus & 6 & 13 & 39 & 2 & 0 & 64 & 0 & 5 \\
\hline Neomys anomalus & 0 & 1 & 28 & 2 & 0 & 31 & 0 & 23 \\
\hline Neomys fodiens & 0 & 0 & 18 & 1 & 0 & 1 & 0 & 5 \\
\hline Talpa europaea & 0 & 0 & 0 & 0 & 0 & 0 & 0 & 0 \\
\hline Vespertilio murinus & 0 & 1 & 0 & 0 & 0 & 0 & 0 & 0 \\
\hline Muscardinus avellanarius & 1 & 0 & 1 & 0 & 0 & 2 & 0 & 0 \\
\hline Microtus agrestis & 8 & 4 & 27 & 5 & 2 & 7 & 0 & 15 \\
\hline Microtus arvalis & 129 & 84 & 162 & 44 & 76 & 15 & 31 & 71 \\
\hline Microtus subterraneus & 12 & 2 & 15 & 2 & 6 & 0 & 1 & 4 \\
\hline Arvicola amphibius & 7 & 3 & 1 & 0 & 0 & 0 & 4 & 0 \\
\hline Myodes glareolus & 4 & 1 & 6 & 1 & 0 & 4 & 1 & 4 \\
\hline Apodemus agrarius & 20 & 2 & 9 & 1 & 0 & 3 & 2 & 11 \\
\hline Apodemus flavicollis & 28 & 7 & 2 & 3 & 0 & 0 & 2 & 7 \\
\hline Apodemus sylvaticus & 37 & 15 & 13 & 7 & 9 & 1 & 11 & 7 \\
\hline Apodemus sp. & 22 & 14 & 7 & 3 & 2 & 2 & 3 & 4 \\
\hline Micromys minutus & 1 & 1 & 4 & 0 & 0 & 11 & 0 & 7 \\
\hline Mus musculus & 10 & 1 & 3 & 2 & 0 & 1 & 1 & 16 \\
\hline Mus spicilegus & 2 & 0 & 0 & 0 & 0 & 0 & 0 & 0 \\
\hline Rattus norvegicus & 0 & 0 & 3 & 0 & 0 & 0 & 0 & 1 \\
\hline Rattus sp. & 1 & 0 & 0 & 0 & 0 & 0 & 0 & 0 \\
\hline Passer sp. & 1 & 0 & 3 & 0 & 0 & 0 & 0 & 0 \\
\hline Sylvia sp. & 0 & 0 & 3 & 0 & 3 & 0 & 0 & 0 \\
\hline Fringilla sp. & 0 & 0 & 1 & 0 & 0 & 0 & 0 & 0 \\
\hline Hirundo sp. & 0 & 0 & 0 & 0 & 0 & 0 & 0 & 0 \\
\hline Aves indet. & 4 & 1 & 1 & 0 & 0 & 0 & 0 & 4 \\
\hline Anura (Rana sp.) & 0 & 0 & 1 & 0 & 0 & 0 & 0 & 0 \\
\hline Insecta & 0 & 0 & 0 & 0 & 0 & 0 & 0 & 1 \\
\hline Prey & 378 & 188 & 564 & 100 & 106 & 253 & 57 & 228 \\
\hline Pellet & 150 & 76 & 156 & 50 & 60 & 46 & 33 & 85 \\
\hline
\end{tabular}


Table 1b. Number of prey items in Barn Owl pellets by sample sites (8-13) 1b. táblázat A köpet-lelőhelyekről (8-13) előkerült zsákmányállatok egyedszáma

\begin{tabular}{|c|c|c|c|c|c|c|c|c|}
\hline Site number & $8 a$. & $8 b$. & 9. & 10. & 11. & 12. & 13. & $\Sigma$ \\
\hline 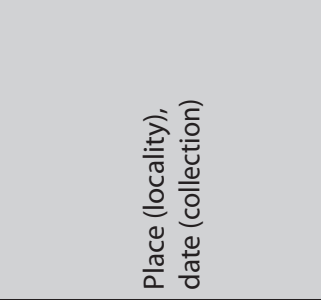 & 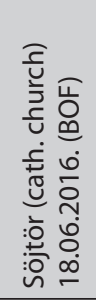 & 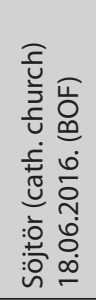 & 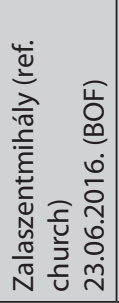 & 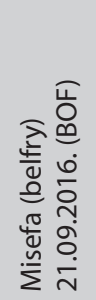 & 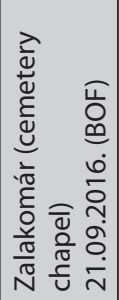 & 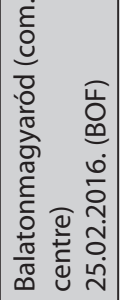 & 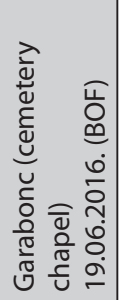 & \\
\hline UTM $(10 \times 10 \mathrm{~km})$ & XM47 & XM47 & XM47 & XM58 & XM65 & XM66 & XM66 & \\
\hline Crocidura leucodon & 17 & 1 & 6 & 1 & 0 & 23 & 1 & 132 \\
\hline Crocidura suaveolens & 18 & 13 & 8 & 3 & 2 & 30 & 5 & 185 \\
\hline Sorex araneus & 39 & 5 & 15 & 3 & 6 & 18 & 6 & 433 \\
\hline Sorex minutus & 13 & 0 & 1 & 0 & 0 & 8 & 6 & 157 \\
\hline Neomys anomalus & 2 & 2 & 14 & 0 & 1 & 6 & 4 & 114 \\
\hline Neomys fodiens & 0 & 0 & 0 & 0 & 0 & 2 & 1 & 28 \\
\hline Talpa europaea & 1 & 0 & 0 & 0 & 0 & 0 & 0 & 1 \\
\hline Vespertilio murinus & 0 & 0 & 0 & 0 & 0 & 0 & 0 & 1 \\
\hline Muscardinus avellanarius & 2 & 0 & 0 & 0 & 0 & 2 & 0 & 8 \\
\hline Microtus agrestis & 4 & 2 & 2 & 0 & 0 & 6 & 0 & 82 \\
\hline Microtus arvalis & 102 & 72 & 54 & 40 & 4 & 98 & 30 & 1012 \\
\hline Microtus subterraneus & 5 & 8 & 0 & 6 & 0 & 3 & 0 & 64 \\
\hline Arvicola amphibius & 4 & 2 & 0 & 0 & 1 & 1 & 0 & 23 \\
\hline Myodes glareolus & 8 & 0 & 1 & 2 & 0 & 1 & 0 & 33 \\
\hline Apodemus agrarius & 17 & 17 & 11 & 0 & 2 & 12 & 3 & 110 \\
\hline Apodemus flavicollis & 31 & 14 & 3 & 20 & 0 & 3 & 16 & 136 \\
\hline Apodemus sylvaticus & 24 & 5 & 6 & 24 & 2 & 6 & 4 & 171 \\
\hline Apodemus sp. & 33 & 6 & 6 & 16 & 8 & 4 & 5 & 135 \\
\hline Micromys minutus & 7 & 2 & 2 & 1 & 1 & 9 & 0 & 46 \\
\hline Mus musculus & 7 & 1 & 6 & 1 & 2 & 3 & 2 & 56 \\
\hline Mus spicilegus & 0 & 0 & 0 & 0 & 0 & 0 & 0 & 2 \\
\hline Rattus norvegicus & 25 & 0 & 4 & 0 & 4 & 0 & 4 & 41 \\
\hline Rattus sp. & 1 & 0 & 0 & 0 & 0 & 0 & 0 & 2 \\
\hline Passer sp. & 0 & 0 & 1 & 0 & 0 & 0 & 0 & 5 \\
\hline Sylvia sp. & 1 & 0 & 0 & 0 & 0 & 0 & 0 & 7 \\
\hline Fringilla sp. & 0 & 0 & 0 & 0 & 0 & 0 & 0 & 1 \\
\hline Hirundo sp. & 2 & 0 & 0 & 0 & 0 & 0 & 4 & 6 \\
\hline Aves indet. & 3 & 0 & 2 & 0 & 2 & 4 & 4 & 25 \\
\hline Anura (Rana sp.) & 0 & 0 & 0 & 0 & 0 & 0 & 0 & 1 \\
\hline Insecta & 1 & 0 & 0 & 0 & 3 & 0 & 0 & 5 \\
\hline Prey & 367 & 150 & 142 & 117 & 38 & 239 & 95 & 3022 \\
\hline Pellet & 167 & 60 & 47 & 54 & 23 & 55 & 44 & 1106 \\
\hline
\end{tabular}


Iklódbördöce, Rédics and Balatonmagyaród) (Table 1a,b), whereas previously was proved only from Óhíd (Szép \& Purger 2013). The Common Vole (Microtus arvalis) made up $33.48 \%$ of mammalian prey (Table 1a,b), it has been shown in previous surveys in Nagykanizsa, Nagykapornak, Pacsa, Vindornyaszőlős, Zalaszentgyörgy (Schmidt 1976), Mihályfa (Lázár 1983), Pölöske (Ács 1984), Balatonmagyaród (Nagy 1994), Kisgörbő and Óhíd (Szép \& Purger 2013). The Field Vole (M. agrestis), the Common Pine Vole (M. subterraneus) and the Bank Vole (Myodes glareolus) were found in the pellets collected in seven UTM squares, the Water Vole (Arvicola amphibius) turned up in six squares (Table 1a,b). These species have already been identified in Pacsa (Schmidt 1976), Pölöske (Ács 1984), Kisgörbő and Óhíd (Szép \& Purger 2013). Furthermore, the Field Vole, the Common Pine Vole and the Bank Vole were found in Nagykapornak (Schmidt 1976) and Balatonmagyaród (Nagy 1994), as well as the Field Vole, the Common Pine Vole and the Water Vole were also found in Mihályfa (Lázár 1983). The presence of the Bank Vole has been shown in Homokkomárom and Vindornyaszőlös (Schmidt 1976). During our study the presence of the Root Vole (M. oeconomus) has not been confirmed, but it was previously found in the surroundings of Kis-Balaton, Keszthely (Éhik 1953) and Balatonmagyaród (Schmidt 1976).

The Striped Field Mouse (Apodemus agrarius) was found in most of our samples and in previous studies in Homokkomárom (Schmidt 1976), Pölöske (Ács 1984), Balatonmagyaród (Nagy 1994), Kisgörbő and Óhíd (Szép \& Purger 2013). The Yellow-necked Mouse (A. flavicollis) were found in the larger samples and the Wood Mouse (A. sylvaticus) in all samples (Table $1 a, b)$. In most of the previous studies these two species were not distinguished due to the difficulties in identification of the skeletal parameters (Cserkész \& Horváth 2007). Therefore, few data is known from pellets about the distribution of these species: e.g. Kisgörbő and Óhíd (Szép \& Purger 2013). The Harvest Mouse (Micromys minutus) was presented in most of the samples with a small number of individuals (Table 1a,b). It has already been known from Homokkomárom, Nagykapornak, Nagykanizsa, Pacsa, Zalaszentgyörgy (Schmidt 1976), Mihályfa (Lázár 1983), Pölöske (Ács 1984), Balatonmagyaród (Nagy 1994), Kisgörbő and Óhíd (Szép \& Purger 2013). The Eastern House Mouse was found in the pellets in all samples with the exception of Barlahida (Table 1a,b) and earlier it was found in Zalaegerszeg (Greschik 1911), Homokkomárom, Nagykapornak, Pacsa, (Schmidt 1976), Mihályfa (Lázár 1983), Pölöske (Ács 1984), Balatonmagyaród (Nagy 1994), Kisgörbő and Óhíd (Szép \& Purger 2013). The remains of the Steppe Mouse were detected only from Rédics (Table la,b), previously there was no data about the occurrence of this species in Zala County (Bihari 2007b). The remains of the Brown Rat (Rattus norvegicus) were found in half of the samples (Table 1a,b), but earlier were found only from the pellets collected in Óhíd (Szép \& Purger 2013).

\section{Analysis of the landscape structure and mosaic}

A positive correlation ( $R=0.60, P=0.032)$ was shown between the diversity of small mammal fauna and the landscape complexity of the hunting area (Figure 2). It is well-known that the diversity of the wildlife is also increasing with the diversity of the environment and its 


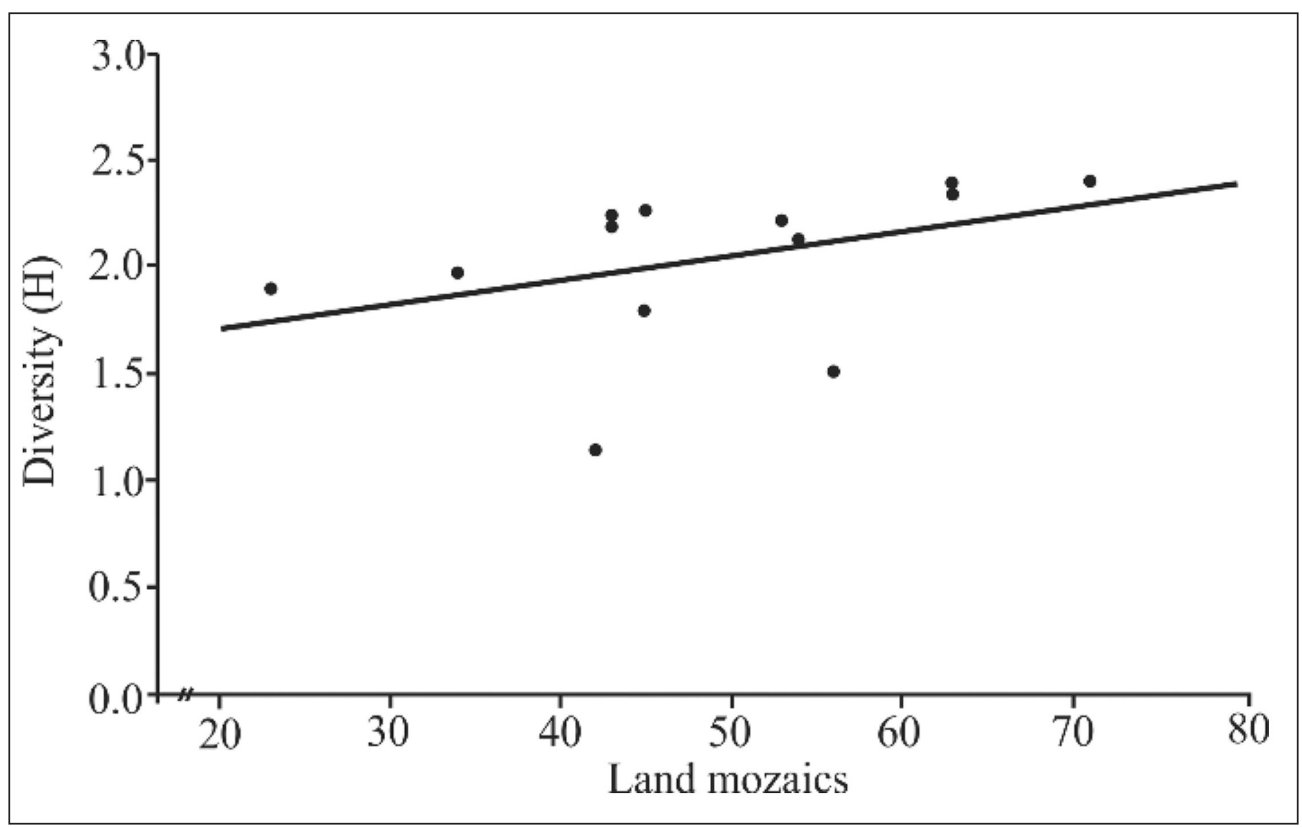

Figure 2. Variation of the diversity of the prey species depending on the landscape complexity of the hunting area

2. ábra A zsákmányolt fajok diverzitásának változása a vadászterület mozaikosságának függvényében

resources (Tews et al. 2004). As the number of various habitat patches is growing, the proportion of edges and the diversity of small mammal fauna are also increasing (Butet et al. 2006), which may be advantageous for the Barn Owl that prefers linear landscape features during their hunting (Martinez \& Zuberogoitia 2004).

The relative abundance of Wood Mouse showed significant positive correlation with the landscape mosaic (Table 2). Negative relationship was found between the relative abundance of Lesser White-toothed Shrew, the Miller's Water Shrew, the Striped Field Mouse and the HarTable 2. Species related to landscavest Mouse with the landscape mosaic (Table 2).

The relative abundance of small mammal species was also related to certain types of landscape structure of the hunting area. The frequency of Common Shrew positively correlated with the total area of non-irrigated arable land $(R=0.59, P=0.033)$. Previous studies conducted in Hungary suggested that this species prefers the wet habitats with dense vegetation (Horváth 2007a), though in Czech Republic it has also been caught in sugar beet and alfalfa fields as well as in tree lines on the edge of the fields (Heroldová et al. 2007). In England the results of pe complexity, correlation coefficients (Rs) and significance level $(P)$

2. táblázat A táj mozaikosságával kapcsolatban álló fajok korrelációs koefficiensei (Rs) és szignifikancia szintjei $(P)$

\begin{tabular}{|l|r|c|}
\hline \multicolumn{1}{|c|}{ Species/Faj } & $\boldsymbol{R}$ & $\boldsymbol{P}$ \\
\hline Crocidura suaveolens & -0.61 & 0.026 \\
\hline Neomys anomalus & -0.74 & 0.004 \\
\hline Apodemus agrarius & -0.56 & 0.044 \\
\hline Micromys minutus & -0.83 & 0.001 \\
\hline Apodemus sylvaticus & 0.75 & 0.003 \\
\hline
\end{tabular}


trapping also showed a positive correlation between the abundance of this species and the proportion of arable land (Fischer et al. 2011).

The relative abundance of Common Dormouse was also correlated with non-irrigated arable land $(R=0.63, P=0.020)$. This species prefers forest habitats (Bakó 2007), occurs in tree lines, hedges and small forest patches but also rarely moves in open areas (Büchner 2008).

Based on our results, the relative abundance of Field Vole positively correlated with natural grassland area $(R=0.69, P=0.009)$. Literature data also showed that most important habitats of this species are wetland meadows and grazed grasslands (Horváth 2007b).

The relative abundance of Common Vole positively correlated with the proportion of broad-leaved forests in Barn Owls' hunting areas $(R=0.63, P=0.024)$. This species prefers the agricultural areas (Gubányi \& Horváth 2007) and it mostly avoids forest habitats (Gouveia et al. 2016). The positive correlation in our study can be explained by the fact that there was a large number of farmlands around each sampling site, where the Common Vole was probably abundant.

The relationship between the relative abundance of Common Pine Vole with the coniferous $(R=0.80, P=0.001)$ and mixed forests $(R=0.59, P=0.033)$ was positive. This is partly supported in the literature, as according to Horváth $(2007 \mathrm{c})$ this species prefers deciduous forests.

The Stripped Field Mouse showed a positive correlation with the discontinuous urban fabric $(R=0.69, P=0.010)$. Its strong dependence on urbanized habitats has already been observed in other areas as it may appear in village buildings, and this species tolerates degraded habitats (Bihari 2007c, Łopucki et al. 2013).

The relative abundance of Yellow-necked Mouse positively correlated with the vineyards in the hunting area $(R=0.57, P=0.043)$. Individuals of this species often come from woody areas but are far less common on the edge of agricultural land (Cserkész \& Horváth 2007). Since Barn Owls rarely hunt in the closed forests, it is likely that they are caught in edges (Taylor 1994).

The relative abundance of the Wood Mouse showed a positive relationship with several landscape types, the land principally occupied by agriculture, with significant areas of natural vegetation $(R=0.70, P=0.007)$, the broad-leaved forests $(R=0.60, P=0.031)$ and the coniferous forest $(R=0.65, P=0.016)$. As a generalist species it can tolerate wide scale of the environmental factors and often occur in forests beside agricultural land as well (Tattersall et al. 2001, Schlinkert et al. 2016).

The abundance of Eastern House Mouse showed positive correlation with the discontinuous urban areas $(R=0.63, P=0.021)$ and the peat bogs area $(R=0.56, P=0.047)$. The species are most often found in settlements (Bihari 2007d, Lesiński \& Gryz 2011), but according to our knowledge it's occurrence in the peat bogs is not usual.

The Brown Rat also had a positive relationship with the discontinuous urban fabric areas ( $R=0.58, P=0.038)$, as it is like the Eastern House Mouse synantropic species and linked to human settlements (Horváth 2007d, Lesiński \& Gryz 2011).

We found a positive correlation between the landscape mosaics of the hunting area and the diversity of the preyed small mammals. Significant correlations were found between the 
relative abundance of some small mammal species and the landscape structure of the potential hunting area of owls, most of which were consistent with the habitat preference of some species. Our results show that the analysis of the Barn Owls' diet, by the distribution of the number of common small mammal species is in accordance with the land use and thus also suitable for landscape ecological analysis.

\section{Acknowledgements}

We would like to thank the University of Pécs, the PhD School of Biology and Sport Biology and the help of the Barn Owl Foundation staff in collecting the pellets.

\section{References}

Ács, A. 1984. Zalai adatok a gyöngybagoly (Tyto alba) táplálkozásához [Data on the diet of Barn Owl (Tyto alba) in Zala County]. - Madártani Tájékoztató jan-márc., pp. 62-63. (in Hungarian)

Askew, N. P., Searle, J. B. \& Moore, N. P. 2007. Prey selection in a Barn Owl Tyto alba. - Bird Study 54(1): 130132. DOI: $10.1080 / 00063650709461465$

Bakó, B. 2007. Mogyorós pele Muscardinus avellanarius [Common Dormouse]. - In: Bihari, Z., Csorba, G. \& Heltai, M. (eds.) Magyarország emlőseinek atlasza [Atlas of mammals in Hungary]. - Kossuth Kiadó, Budapest, pp. 146-147. (in Hungarian with English Summary)

Bihari, Z. 2007a Közönséges vakond Talpa europaea [Common Mole]. - In: Bihari, Z., Csorba, G. \& Heltai, M. (eds.) Magyarország emlőseinek atlasza [Atlas of mammals in Hungary]. - Kossuth Kiadó, Budapest, pp. 6768. (in Hungarian with English Summary)

Bihari, Z. 2007b Güzüegér Mus spicilegus [Steppe Mouse]. - In: Bihari, Z., Csorba, G. \& Heltai, M. (eds.) Magyarország emlőseinek atlasza [Atlas of mammals in Hungary]. - Kossuth Kiadó, Budapest, pp. 195-196. (in Hungarian with English Summary)

Bihari, Z. 2007c Pirók erdeiegér Apodemus agrarius [Striped Field Mouse]. - In: Bihari, Z., Csorba, G. \& Heltai, M. (eds.) Magyarország emlöseinek atlasza [Atlas of mammals in Hungary]. - Kossuth Kiadó, Budapest, pp. 179-180. (in Hungarian with English Summary)

Bihari, Z. 2007d Házi egér Mus musculus [Eastern House Mouse]. - In: Bihari, Z., Csorba, G. \& Heltai, M. (eds.) Magyarország emlőseinek atlasza [Atlas of mammals in Hungary]. - Kossuth Kiadó, Budapest, pp. 193-194. (in Hungarian with English Summary)

Bihari, Z., Csorba, G. \& Heltai, M. (eds.) 2007. Magyarország emlőseinek atlasza [Atlas of mammals in Hungary]. - Kossuth Kiadó, Budapest (in Hungarian with English Summary)

Bunn, D. S., Warburton, A. B. \& Wilson R. D. S. 1982. The Barn Owl. - T \& AD Poyser, Calton

Butet, A., Paillat, G. \& Delettre, Y. 2006. Factors driving small rodents assemblages from field boundaries in agricultural landscapes of western France. - Landscape Ecology 21(3): 449-461. DOI: 10.1007/s10980-005-4118-6

Büchner, S. 2008. Dispersal of Common Dormice Muscardinus avellanarius in a habitat mosaic. - Acta Theriologica 53(3): 259-262.

Cserkész, T. \& Horváth, Gy. 2007. Sárganyakú erdeiegér Apodemus flavicollis [Yellow-necked Mouse]. - In: Bihari, Z., Csorba, G. \& Heltai, M. (eds.) Magyarország emlőseinek atlasza [Atlas of mammals in Hungary]. Kossuth Kiadó, Budapest, pp. 181-182. (in Hungarian with English Summary)

Cooke, D., Nagle, A., Smiddy, P., Fairley, J. \& Muircheartaigh, I. 1996. The diet of the Barn Owl (Tyto alba) in County Cork in relation to land use. - Biology \& Environment: Proceedings of the Royal Irish Academy 96B(2): 97-111.

de la Peña, N. M, Butet, A., Delettre, Y., Paillat, G., Morant, P., Le Du, L. \& Burel, F. 2003. Response of the small mammal community to changes in western French agricultural landscapes. - Landscape Ecology 18(3): 265-278.

Dövényi, Z., Ambrózy, P., Juhász, Á., Marosi, S., Mezősi, G., Michalkó, G., Somogyi, S., Szalai, Z. \& Tiner, T. 2010. Magyarország kistájainak katasztere [Inventory of microregions in Hungary]. - HAS Geographical Research Institute, Budapest (in Hungarian) 
Estók, P., Bihari, Z., \& Gombkötő, P. 2007. Fehértorkú denevér Vespertilio murinus [Parti-coloured Bat]. - In: Bihari, Z., Csorba, G. \& Heltai, M. (eds.) 2007. Magyarország emlőseinek atlasza [Atlas of mammals in Hungary]. - Kossuth Kiadó, Budapest, pp. 105-106. (in Hungarian with English Summary)

Éhik, Gy. 1953. The occurence of the Root-vole (Microtus oeconomus Pall.) at the Kisbalaton. - Annales historico-naturales Musei nationalis hungarici 3: 251-256.

Fehér, Cs. E. 1996. Korai denevér (Nyctalus noctula) szokatlanul nagyarányú előfordulása gyöngybagoly (Tyto alba) köpeteiben [Unusual abundant occurence of Noctule (Nyctalus noctula) in Barn Owl (Tyto alba) pellets]. - Hungarian Bat Research News 2: 41-42. (in Hungarian with English Summary)

Fehér, Cs. E., Bekő, T. \& Torma T. 2005. Épületlakó denevérfajok kutatásának eredményei a Nyugat-Dunántúlon [Results of survey of bats living in buildings in western Transdanubian region]. - II. Magyar Denevérvédelmi Konferencia Absztrakt Kötete, pp. 16-18. (in Hungarian with English Summary)

Feranec, J., Ot'ahel', J. \& Pravda, J. 1995. Proposal for a methodology and nomenclature scale 1:50.000 CORINE Land Cover Project, Final Report. - Institute of Geography, Slovak Academy of Sciences, Bratislava

Fischer, C., Thies, C. \& Tscharntke, T. 2011. Small mammals in agricultural landscapes: Opposing responses to farming practices and landscape complexity. - Biological Conservation 144(3): 1130-1136. DOI: 10.1016/j. biocon.2010.12.032

Gouveia, A. R., Bjørnstad, O. N. \& Tkadlec, E. 2016. Dissecting geographic variation in population synchrony using the Common Vole in central Europe as a test bed. - Ecology and Evolution 6(1): 212-218. DOI: $10.1002 /$ ece 3.1863

Gubányi, A. \& Horváth, Gy. 2007. Mezei pocok Microtus arvalis [Common Vole]. - In: Bihari, Z., Csorba, G. \& Heltai, M. (eds.) Magyarország emlőseinek atlasza [Atlas of mammals in Hungary]. - Kossuth Kiadó, Budapest, pp. 162-163. (in Hungarian with English Summary)

Greschik, J. 1911. Hazai ragadozómadaraink gyomor- és köpettartalom vizsgálata - Magen- und Gewölluntersuehungen unserer einheimischen Raubvögel [Survey of pellets and stomach content of birds of prey in Hungary]. - Aquila 18: 141-177. (in Hungarian and German)

Hammer, Ø., Harper, D. A. T. \& Ryan, P. D. 2001. PAST: Paleontological statistics software package for education and data analysis. - Paleontologia Electronica 4: 1-9.

Heisler, L. M., Somers, C. M. \& Poulin, R. G. 2016. Owl pellets: a more effective alternative to conventional trapping for broad-scale studies of small mammal communities. - Methods in Ecology and Evolution 7(1): 96-103. DOI: 10.1111/2041-210X.12454

Heroldová, M., Bryja, J., Zejda, J. \& Tkadlec, E. 2007. Structure and diversity of small mammal communities in agriculture landscape. - Agriculture Ecosystems \& Environment 120(2-3): 206-210. DOI: 10.1016/j. agee.2006.09.007

Horváth, Gy. 2007a Erdei cickány Sorex araneus [Common Shrew]. - In: Bihari, Z., Csorba, G. \& Heltai, M. (eds.). Magyarország emlőseinek atlasza [Atlas of mammals in Hungary]. - Kossuth Kiadó, Budapest, pp. 59-60. (in Hungarian with English Summary)

Horváth, Gy. 2007b Csalitjáró pocok Microtus agrestis [Field Vole]. - In: Bihari, Z., Csorba, G. \& Heltai, M. (eds.) Magyarország emlőseinek atlasza [Atlas of mammals in Hungary]. - Kossuth Kiadó, Budapest, pp. 160-161. (in Hungarian with English Summary)

Horváth, Gy. 2007c Földi pocok Microtus subterraneus [Common Pine Vole]. - In: Bihari, Z., Csorba, G. \& Heltai, M. (eds.) Magyarország emlőseinek atlasza [Atlas of mammals in Hungary]. - Kossuth Kiadó, Budapest, pp. 166-167. (in Hungarian with English Summary)

Horváth, Gy. 2007d Vándorpatkány Rattus norvegicus [Brown Rat]. - In: Bihari, Z., Csorba, G. \& Heltai, M. (eds.) Magyarország emlőseinek atlasza [Atlas of mammals in Hungary]. - Kossuth Kiadó, Budapest, pp. 197-198. (in Hungarian with English Summary)

Kalivoda, B. 1999. A magyar bagoly-táplálkozástani irodalom annotált bibliográfiája [The annoted bibliography of the Hungarian literature on owl food]. - Crisicum 2: 221-254. (in Hungarian with English Summary)

Király, G., Molnár, Zs., Bölöni, J., Csiky, J. \& Vojtkó, A. (eds.) 2008. Magyarország földrajzi kistájainak növényzete [Vegetation of geographical microregions in Hungary]. - MTA ÖBKI, Vácrátót (in Hungarian)

Kryštufek, B. \& Janžekovič, F. (eds.) 1999. Ključ za določanje vretenčarjev Slovenije [Key for identification of vertebrates in Slovenia]. - DZS, Lubljana (in Slovenian)

Lázár, P. 1983. Adatok Sümeg környéke apróemlősfaunájához bagoly-köpetvizsgálatok alapján [Data on small mammals fauna based on owl pellets analysis in the Sümeg surroundings]. - Folia Musei Historico-Naturalis Bakonyiensis 2: 217-228. (in Hungarian with German Summary) 
Lesiński, G. \& Gryz, J. B. 2011. How protecting a suburban forest as a natural reserve effected small mammal communities. - Urban Ecosystems 15(1):103-110. DOI: 10.1007/s11252-011-0190-7

Łopucki, R., Mróz, I., Berliński, Ł. \& Burzych, M. 2013. Effects of urbanization on small-mammal communities and the population structure of synurbic species: an example of a medium-sized city. - Canadian Journal of Zoology 91(8): 554-561. DOI: 10.1139/cjz-2012-0168

Lovari, S., Renzoni, A. \& Fondi, R. 1976. The predatory habits of the Barn Owl (Tyto alba Scopoli) in relation to the vegetation cover. - Bolletino di Zoologia 43(1-2): 173-191. DOI: 10.1080/11250007609434894

Macholán, M. 1996. Key to European house mice (Mus). - Folia Zoologica 45(3): 209-217.

Martinez, J. A. \& Zuberogoitia, I. 2004. Habitat preferences and causes of population decline for Barn Owls Tyto alba: a multi-scale approach. - Ardeola 51(2): 303-317.

März, R. 2011. Gewöll- und Rupfungskunde [The science of pellets and pluck]. - Aula-Verlag, Wiebelsheim (in German)

Meek, W. R., Burman, P. J., Sparks R. H., Nowakowski, M. \& Burman, N. J. 2012. The use of Barn Owl Tyto alba pellets to assess population change in small mammals. - Bird Study 59(2): 166-174. DOI: $10.1080 / 00063657.2012 .656076$

Mikkola, H. 1983. Owls of Europe. - T \& AD Poyser, Calton

Nagy, S. 1994. Adatok a gyöngybagoly (Tyto alba) táplálkozásához [Data on feeding of Barn Owl (Tyto alba)]. Madártani Tájékoztató júl-dec., p. 32. (in Hungarian)

Purger, J. J. 2014. Survey of the small mammal fauna in north-western Somogy county (Hungary), based on Barn Owl Tyto alba (Scopoli, 1769) pellet analysis. - Natura Somogyiensis 24: 293-304.

Purger, J. J. 2016. Adatok Somogy megye kisemlős faunájának ismeretéhez, gyöngybagoly Tyto alba (Scopoli, 1769) köpetek vizsgálata alapján [Data to the knowledge of small mammal fauna of Somogy county (Hungary), based on Barn Owl Tyto alba (Scopoli, 1769) pellet analysis]. - A Kaposvári Rippl-Rónai Múzeum Közleményei 4: 91-108. (in Hungarian with English Summary)

Rodríguez, C. \& Peris, S. J. 2007. Habitat associations of small mammals in farmed landscapes: implications for agri-environmental schemes. - Animal Biology 57(3): 301-314. DOI: 10.1163/157075607781753092

Roulin, A. 2016a Strong decline in the consumption of invertebrates by Barn Owls from 1860 to 2012 in Europe. - Bird Study 63(1): 146-147. DOI: 10.1080/00063657.2015.1125440

Roulin, A. 2016b Shrews and moles are less often captured by European Barn Owls Tyto alba nowadays than 150 years ago. - Bird Study 63(4): 559-563. DOI: 10.1080/00063657.2016.1240149

Roulin, A. \& Christe, P. 2013. Geographic and temporal variation in the consumption of bats by European Barn Owls. - Bird Study 60(4): 561-569. DOI: 10.1080/00063657.2013.847051

Schlinkert, H., Ludwig, M., Batáry, P., Holzschuh, A., Kovács-Hostyánszki, A., Tscharntke, T. \& Fischer, C. 2016. Forest specialist and generalist small mammals in forest edges and hedges. - Wildlife Biology 22(3): 86-94. DOI: $10.2981 /$ wlb.00176

Schmidt, E. 1967a Néhány adat a gyöngybagoly táplálkozásökológiájához [Supplements for the feeding ecology of Barn Owl]. - Aquila 73-74: 109-116. (in Hungarian with German Summary)

Schmidt, E. 1967b Bagolyköpetvizsgálatok [Owl pellet analyses]. - Magyar Madártani Intézet, Budapest (in Hungarian)

Schmidt, E. \& Topál, Gy. 1971. Denevérmaradványok magyarországi bagolyköpetekből [Bats in owl pellets from Hungary]. - Vertebrata Hungarica 12: 93-102. (in Hungarian with German Summary)

Schmidt, E. 1973. A gyöngybagoly (Tyto alba) és az erdei fülesbagoly (Asio otus) legfontosabb táplálékállatai Magyarországon [The most important prey species of Barn Owl (Tyto alba) and Long-eared Owl (Asio otus) in Hungary]. - Aquila 76-77: 55-64. (in Hungarian with German Summary)

Schmidt, E. 1974. Über die Verbreitung und Wohndichte der Kleinwühlmaus (Pitymys subterraneus [De Selys-Longchamps]) in Ungarn [The distribution and abundance of the Common Pine Vole (Pitymys subterraneus [De Selys-Longchamps]) in Hungary]. - Vertebrata Hungarica 15: 45-52. (in German)

Schmidt, E. 1976. Kleinsäugerfaunistische Daten aus Eulengewöllen in Ungarn [Small mammal data from Barn Owl pellets in Hungary]. - Aquila 82: 119-144. (in German)

Seamon, J. O. \& Adler, G. H. 1996. Population performance of generalist and specialist rodents along habitat gradients. - Canadian Journal of Zoology 74(6): 1130-1139. DOI: 10.1139/z96-125

Shannon, C. E. \& Weaver, W. 1949. The Mathematical Theory of Communication. - University Illinois Press, Urbana

Szép, D. \& Purger, J. J. 2013. Óhid és Kisgörbő környékének (Zala megye) kisemlős faunája gyöngybagoly (Tyto alba) köpetek vizsgálata alapján [Small mammal fauna of the surroundings of Óhíd and Kisgörbő (Zala 
County, Hungary), based on Barn Owl (Tyto alba) pellet analysis]. - Folia Musei Historico-Naturalis Bakonyiensis 30: 147-152. (in Hungarian with English Summary)

Szűcs, D., Horváth K. \& Horváth, G. F. 2014. Comparing small mammal faunas based on Barn Owl (Tyto alba) pellets collected in two different lowland landscapes. - Natura Somogyiensis 24: 305-320.

Tattersall, F. H., Macdonald, D. W., Hart, B. J., Manley, W. J. \& Feber, R. E. 2001. Habitat use by Wood Mice (Apodemus sylvaticus) in a changeable arable landscape. - Journal of Zoology 255(4): 487-494. DOI: $10.1017 / \mathrm{S} 095283690100156 \mathrm{X}$

Taylor, I. R. 1994. Barn Owls: predator-prey relationships and conservation. - Cambridge University Press, Cambridge

Tews, J., Brose, U., Grimm, V., Tielbörger, K., Wichmann, M. C., Schwager, M. \& Jeltsch, F. 2004. Animal species diversity driven by habitat heterogeneity/diversity: the importance of keystone structures. - Journal of Biogeography 31(1): 79-92. DOI: 10.1046/j.0305-0270.2003.00994.x

Tores, M., Motro, Y., Motro, U. \& Yom-Tov, Y. 2005. The Barn Owl - a selective opportunist predator. - Israel Journal of Zoology 51(4): 349-360. DOI: 10.1560/7862-9E5G-RQJJ-15BE

Torre, I., Arrizabalaga, A. \& Flaquer, C. 2004. Three methods for assessing richness and composition of small mammal communities. - Journal of Mammalogy 85(3): 524-530. DOI: 10.1644/BJK-112

Torre, I., Gracia-Quintas, L., Arrizabalaga, A., Baucells, J. \& Mario, D. 2015. Are recent changes in the terrestrial small mammal communities related to land use change? A test using pellet analyses. - Ecological Research 30(5): 813-819. DOI: 10.1007/s11284-015-1279-x

Tvrtković, N. 1979. Razlikovanje i određivanje morfološki sličnih vrsta podroda Sylvaemus Ognev \& Vorobiev 1923. (Rodentia, Mammalia) [Distinguishing and determination of the morphologically similar species of subgenus Sylvaemus Ognev et Vorobiev 1923 (Rodentia, Mammalia)]. - Rad JAZU 383: 155-186. (in Croatian with German Summary)

Tvrtković, N., Đulić, B. \& Mrakovčić, M. 1980. Distribution, species characters, and variability of the Southern Water-shrew, Neomys anomalus Cabrera, 1907 (Insectivora, Mammalia) in Croatia. - Biosistematika 6(2): 187-201.

Ujhelyi, P. 1989. A magyarországi vadonélő emlősállatok határozója (küllemi és csonttani bélyegek alapján) [Key for identification of wild mammals of Hungary (on the base of habitus and features of sceleton)]. - A Magyar Madártani és Természetvédelmi Egyesület (MME) Könyvtára 1. Budapest (in Hungarian)

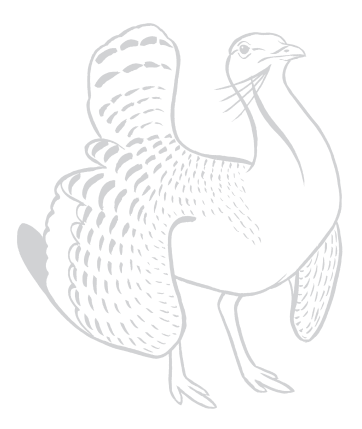

